\title{
Critical Thinking and Speaking Proficiency: A Mixed-method Study
}

\author{
Reza Vahdani Sanavi \\ Islamic Azad University, Roodehen Branch, Tehran, Iran \\ Samaneh Tarighat \\ Islamic Azad University, Roodehen Branch, Tehran, Iran
}

\begin{abstract}
The present study was intended to investigate the impact of teaching critical thinking skills on the speaking proficiency of Iranian EFL learners in Tehran, how this impact is explained and the participants' attitudes towards explicit critical-thinking content. To achieve this goal, two groups of female Iranian intermediate EFL learners were compared on their speaking performance, with one group having been trained in critical thinking explicitly and the other as the control group. Both groups were tested prior to and after the training of the experimental group was performed. A mixed-method approach was employed in the analysis of the data. In the quantitative analysis, a quasi-experimental method was adopted to investigate the impact of teaching critical thinking skills on the speaking proficiency of the experimental group in comparison with the control group. The results indicated that teaching critical thinking explicitly has a significantly positive impact on the speaking proficiency of female Iranian adult intermediate EFL learners. Through the qualitative approach, the participants' attitudes towards their training in critical thinking were studied during in-depth interviews. The results are described in detail. Accordingly, explicit instruction of critical thinking in the English class can make a deeper impression of the language taught.
\end{abstract}

Index Terms — critical thinking, speaking proficiency, English as a foreign language (EFL)

\section{INTRODUCTION}

Critical thinking is one of the most modern issues in education around the world, being utilized in the classroom and the curricula as a way to train decisive, open-minded individuals with fair judgmental qualities referred to as cultivated critical thinkers (Paul \& Elder, 2008). Paul and Elder maintained that thinking is inevitable, and all people think, although much of this thinking can be biased, distorted, partial, uninformed or down-right prejudiced, and to achieve excellence in thought one must be cultivated. Therefore, one is not born with critical thinking skills and needs to be trained to learn the skills and fortunately critical thinking can be taught.

ELT has not been ignorant of the importance of critical thinking and English teachers have long tried to employ critical thinking strategies into the English language classroom through problem-solving tasks, thought-provocative questions following reading comprehensions or in class discussions and many more (Devine, 1962).

Despite the fact that the enhancement of life skills has for many years been advocated in the context of education, it seems that, at least in the case of critical thinking, both English language teachers and language learners are lagging behind in Iran (Ketabi, Zabihi, \& Ghadiri, 2012). Iranian students are mostly obliged to memorize and rewrite prethought information at schools as opposed to thinking out their own ideas and assessing facts and not taking those taught by their teachers for granted. Not introduced to the concept of critical thinking at school, Iranian students welcome English language learning in private institutes and/or with the help of private tutors, who go through worldrenowned ELT books written by English-speaking authors who claim that critical thinking strategies were embedded in their course books.

\section{LITERATURE REVIEW}

The history of critical thinking traces its roots in analytic philosophy and pragmatist constructivism which dates back over 2500 years, as in the Buddha's Teachings: mainly in Buddhist texts such as the Kalama Sutta and the Abhidharma (Damirchi, Seyyedi, \& Rahimi, 2012). The term "critical thinking" stems from the mid-late 20th century. It is best said that "there are as many definitions of critical thinking as there are writers on the subject" (Mayfield, 2001, p. 4). One of the briefest, most commonly cited definitions of critical thinking is that it is "thinking about thinking" extracted from the longer definition stating that critical thinking is the art of thinking about your thinking while you are thinking in order to make your thinking better: clearer, more accurate, more defensible" (Paul, as cited in Long, 2003, p. 2).

In the literature belonging to the recent years, a categorized look at the definition of critical thinking has been adopted. Three different approaches to critical thinking have been described. The two first approaches to critical thinking stem from Lewis and Smith (1993) believing in the roots of critical thinking to be in philosophy and psychology. A third critical thinking strand is within the field of education which was first presented by Sternburg (as 
cited in Lai, 2011). Lai (2011) believes that these different approaches have led to different perspectives in defining critical thinking, which include: the philosophical approach, the cognitive psychological approach, and the educational approach.

The writings of Socrates, Plato, Aristotle, and more recently, Lipman and Paul, are examples of the philosophical approach. This approach focuses on the hypothetical critical thinker, listing the numerous qualities and characteristics of the critical thinker and not the behaviors or actions that the critical thinker does. Scholars who work within the philosophical tradition also emphasize standards of thought (as cited in Fahim \& Shakouri, 2012). Sternberg (Sternberg, 1986) noted that this approach somehow looks at the critical thinker rather idealistically, and mostly focuses on what people are capable of doing under hypothetically ideal circumstances. Accordingly, Paul (1992) discussed critical thinking in the context of "perfections of thought" (p. 9). As mentioned above, those who work within the philosophical tradition also emphasize standards of thought. For example, Bailin (2002) defined critical thinking as thinking of a particular quality - essentially good thinking that meets specified criteria or standards of adequacy and accuracy. Further, in the philosophical approach, the application of formal rules of logic is traditionally focused upon (Lewis \& Smith, 1993; Sternberg, 1986). It is clear that one of the limitations of this approach to defining critical thinking is that it is not always in agreement with reality (Sternberg, 1986).

The cognitive psychological approach contrasts with the philosophical perspective in that, first, it tends to focus on how people actually think rather than how they could or should think under ideal circumstances, and second, it defines critical thinking by the types of actions or behaviors critical thinkers can do. Typically, in this approach to defining critical thinking a list of skills or procedures performed by critical thinkers is provided (Lewis \& Smith, 1993). This latter aspect of critical thinking has been criticized by philosophers, for instance, Bailin (2002) claimed that since the actual process of thought is unobservable, cognitive psychologists have tended to focus on the products of such thought—-behaviors or overt skills.

According to Lai (2011), the third approach to critical thinking comes from those working in the field of education, like Bloom (1956) and his associates who have taken part in the discussions revolving around critical thinking. Their taxonomy for information processing skills has been widely cited by educational practitioners when it comes to teaching and assessing higher-order thinking skills, which itself is defined as "the capacity to go beyond the information given, to adopt a critical stance, to evaluate, to have metacognitive awareness and problem solving capacities" (McLoughlin \& Luca, 2000, p. 4). Bloom's taxonomy refers to a classification of the different objectives which educators set for students (learning objectives) (Orlich, Harder, Callahan, Trevisan, \& Brown, 2004) and is hierarchical, with comprehension at the bottom and evaluation at the top. The three highest levels, which include analysis, synthesis, and evaluation, are frequently said to represent critical thinking (Kennedy, Fisher, \& Ennis, as cited in Lai, 2011, p. 8).

Teaching critical thinking.

Educators have long seen critical thinking as a desirable educational outcome. A 1972 study of 40,000 faculty members by the American Council on Education revealed that 97 percent of the respondents indicated the most important goal of undergraduate education is to foster students' ability to think critically (Paul R., 2004). Dewey introduced learning to think" as a primary purpose of education in 1933 (as cited in Halpern, 2003). Bruning, Schraw, Norby and Ronning (2004) maintained that it is important that we are "teaching students how to think rather than what to think" (p. 180). In his book named Pedagogy of the Oppressed, Freire (1970) labeled the traditional system of education present in many countries as the banking system of education as opposed to the problem-posing system of education. In the banking system of education the teacher is the source of information and knows everything while the students know nothing, they are expected to listen only and not to express their opinions, and to be filled by the teacher's narration like empty glasses. On the contrary, the problem posing education is one form of the realization of critical pedagogy in the classroom context and encourages critical thinking. One of the teachers' roles in a problemposing system of education is to problematize situations that are familiar to the students and by presenting them to the students and making them think about those situations in new ways (Fahim \& Shakouri, 2012).

Moon (2008) asserted that critical thinking and its relationship to the educational process has become a central issue. She added that since critical thinking is a process which is involved in any research activity; it can be considered as a principal concept to education, especially at higher levels. In fact, critical thinking is a fundamental goal of learning. According to Lipman (2003) teachers are responsible to develop critical thinking in their students and not just push them from one educational level to the next. Brown (2004) proposes that the objectives of a curriculum in an ideal academic English program should go beyond linguistic factors, and to develop the art of critical thinking. Critical thinking has been identified as one of several skills necessary to prepare students for post-secondary education and the workforce (Lai, 2011). Fisher (2003) also emphasized the significance of teaching critical thinking skills. He maintained that the students' thinking skills do not equip them well enough to overcome the problems that they encounter either in education or in their daily lives, thus they need to be taught critical thinking skills.

Ennis (1989) described four instructional approaches that vary in terms of the extent to which critical thinking skills are taught as an exclusive course versus integrated into regular instruction (cited in Lai, 2011). These include the general approach, the infusion approach, the immersion approach and the mixed approach. In the general approach, direct and explicit instruction in critical thinking takes place in an exclusive course, where critical thinking skills and abilities are emphasized and the instruction of specific subject matter is not involved. Examples and tasks are included 
in order to make the issue more tangible for the students. The content is drawn from problems that students are familiar with and may encounter in their daily lives. Van Gelder (2005), as one of the advocates of the general approach, emphasized the need for "deliberate practice" in exercising critical thinking skills and abilities and stated that this type of practice can only occur when critical thinking is taught explicitly and exclusively as part of the curriculum. However, students must also be taught how to transfer their critical thinking knowledge to a variety of contexts and must be provided with opportunities to practice applying critical thinking skills in diverse contexts. Another scholar advocating this approach is Halpern (2001), who has referred to instruction in general thinking skills, taught as a "broad-based, cross-disciplinary" course, to be the most effective way of teaching critical thinking.

In the infusion approach, in-depth instruction in the subject matter takes place including explicit instruction on general critical thinking principles. This critical thinking instruction is embedded in the context of specific subject matter (Lai, 2011). Somewhat related to the infusion approach is immersion.

In immersion instruction, students are engaged in deep subject-matter instruction. Although critical thinking skills and abilities are part of the content to be learned, critical thinking instruction is not made explicit and remains embedded in the instruction of the subject matter. In other words, critical thinking skills and abilities are not the focus of direct and explicit instruction. Rather, students are expected to acquire these skills as a natural consequence of their engagement with the subject matter (Ennis, 1989). Some of the scholars who defend these approaches include Bailin, Case, Coombs and Daniels (1999), Lipman (1988), Silva (2008) and Case (2005).

The mixed approach is a combination of both the general and subject-specific approaches. Teachers combine exclusive instruction in general critical thinking principles with application of critical thinking skills in the context of specific subject matter. Explicit instruction in critical thinking skills can be incorporated into both the general and the specific components (Ennis, as cited in Lai 2011). This approach is supported by Facione (1990), Paul (1992) and Kennedy, Fisher and Ennis (1991). After reviewing extant research on the various approaches, Kennedy et al. (1991) concluded that the evidence does not support the superiority of any particular approach.

Speaking proficiency

The Oxford Dictionary of Current English (2009) defines speaking as "the action of conveying information or expressing ones' thoughts and feelings in spoken languages” (p.414). Chaney (1998), however, thought of speaking to be a process: "speaking is the process of building and sharing meaning through the use of verbal or non-verbal symbols in a variety of contexts" (p.13). Accordingly, Florez (1999) described speaking as an "interactive" process, which consists of three main stages "producing, receiving and processing information" (p.1). In language teaching and learning, speaking is considered a skill to be practiced and mastered. Nunan (2003) included that "speaking is the productive oral skill; It consists of producing systematic verbal utterance to convey meaning" (p.48) (cited in Hong, 2010).

The Speaking skill is viewed as the most substantial part of an EFL course. The growing need for international communication in the information age, has led many language learners to language classes in order to improve their speaking ability. Even though many students have mastered basic speaking skills, some students have performed much more effectively in the acquisition and their progress in oral communication than others. And those who are more effective communicators experience more success in school and in other areas of their lives (Malmir \& Shoorcheh, 2012). According to Folse (2006), for most people, being able to speak a language means knowing that language since speech is the most fundamental means of communication among human beings. Nevertheless, speaking in a second or foreign language learning context has often been viewed as the most demanding of the four language skills. Speaking a language is especially difficult for foreign language learners because effective oral communication requires the ability to use the language appropriately in social interactions (Fulcher, 2003). Bygate (1987) declared that to become a proficient EFL speaker, studying the knowledge of grammar, vocabulary, pronunciation, intonation, etc. is not adequate but the ability to use this knowledge in order to communicate successfully is indispensable.

Hugh and Lavery (2004) draw our attention to the relationship between language and thought and claimed that the relationship is straightforward. They maintained that "thought is expressed in and through language. But this claim, while true, is an oversimplification ... And we all use words not merely to express our thoughts but also to shape them. Developing our critical thinking skills, therefore, requires an understanding of the ways in which words can (and often fail to) express our thoughts." (p.10)

An overview of related research studies

A number of research studies have been done on critical thinking and language proficiency. In their paper titled "The Relationship between Critical Thinking and Language Proficiency of Malaysian Undergraduates", Rosyati and Rosna (2008) reveal the results of their observation as "Proficiency in English is positively related to critical thinking ability implying that if the undergraduates are proficient in English, their critical thinking ability will also be heightened". Nikoopour, Amini Farsani and Nasiri (2011) published their study of Critical Thinking and Language Learning Strategies in 2011; they found a significant relationship between Iranian use of language learning strategies and their way of thinking. "This positive relation may be a replication of many previous studies concerning the effectiveness of critical thinking on the ultimate success of language learners in the challenging process of foreign language learning". In a study on the relationship between collaborative learning and critical thinking of Iranian EFL learners, Naeini (2005) tested 144 adult English language learners. She divided the participants into two groups: the control group and the 
experimental group. The findings revealed that the experimental group outperformed the control group. Alagozlu (2007) analyzed Turkish students' critical thinking and individual voice in writing, in her study titled critical thinking and voice in EFL writing in which she concludes that students tend to memorize and write what they read rather than filter it through their judgment and reasoning. She declares that the situation fits into the didactic approach or concept-based instruction in the classic educational system where learning is centered on the retention of previously learned information and where no thinking is required. The study suggests seeking remedies to integrate critical thinking into the classroom and the curricula.

After the existence of a significant relationship between critical thinking and different English language skills was indicated, researchers began studying the impact of critical thinking on improving those skills. In a quantitative study conducted by Malmir and Shoorcheh (2012) on the impact of teaching critical thinking on Iranian learners' speaking skill, it was concluded that critical thinking training had a crucial impact on promoting the speaking ability of Iranian EFL learners. They also observed that, "Critical-thinking strategies helped the learners to become active participants in the interaction process by listening carefully to other students' lectures, by judging on those utterances, and by making the best decisions about what to say in response to what has been said in the conversation by other interactants". Shangarffam and Mamipour (2011) studied the impact of teaching critical thinking on Intermediate EFL learners' writing skill and reported that the participants who had had the opportunity to become familiarized with critical thinking techniques and procedures had outperformed the participants with lack of knowledge about critical thinking. Needless to say, in both of the latter studies critical thinking techniques were employed to teach the participants the skills of speaking and/or writing, this was done through debates, media analysis and problem-solving tasks, however, no explicit and exclusive teaching of critical thinking took place.

Though critical thinking is universally regarded as a pillar of higher education (including by employers seeking college graduates), the results of some research studies show that students are not developing their critical thinking skills to the extent that the researchers expect. For their 2009 book, Academically Adrift: Limited Learning on College Campuses, Arum and Rocksa (2009) followed a little over 2,300 college students through their first two years of school. They found "a barely noticeable impact on students' skills in critical thinking, complex reasoning, and writing" and "no statistically significant gains [in these skills] for at least 45 percent of the students."

It is concluded that some studies show outstanding results by teaching learners skills to improve their critical thinking; however some show that the success does not include all learners. This could stem from the methods used by researchers to teach critical thinking. Marin and Halpern (2010) studied two groups of American high school students and concluded that the students receiving explicit instruction showed much larger gains than those who had received imbedded instruction in critical thinking. Cosgrove (2011) conducted a study in Oxford University and concluded that there was a need for an explicit and systematic approach to teaching critical thinking as the students internalized the explicit and required aspects of critical thinking and largely missed those that were implicit. Therefore, research shows that explicit methods of instruction in critical thinking have been more effective.

\section{METHODOLOGY}

\section{A. Participants}

The participants of the present study were 30 female Iranian intermediate- level learners of English, studying at an English institute situated in the north-east of Tehran. Fifty intermediate students were initially tested on their English proficiency through the Cambridge PET test. Those who scored within one standard deviation above and below the mean were selected for the study as a homogeneous group and then randomly assigned to two groups of 15 students, one as the control group and the other as the experimental group.

Both classes were held at the institute and were taught by the researcher. The control group received the mainstream instruction given in all first intermediate level classes of the institute within 20 sessions. The experimental group received the same training in general English as the control group with an additional treatment in critical thinking for 16 sessions of the total 20 sessions. The sixteen sessions of treatment were carried out within the one and half hour of class time and no additional time was devoted to teaching the experimental group.

\section{B. Instrument}

The Preliminary English Test (PET) from Cambridge ESOL exams, by Cambridge University was adopted in this study to a) determine the homogeneity of the participants before the treatment starts, and b) to measure their speaking proficiency before and after the treatment.

The mainstream instruction of general English taught to students of all intermediate classes in the institute includes units one and two of Cambridge Total English course books for Intermediate Students which is covered in twenty sessions of classes held in one month, with each session lasting one and half hours.

The material employed to explicitly teach critical thinking and train the learners in the experimental group was based on the general approach of critical pedagogy. In the general approach, direct and explicit instruction in critical thinking skills is provided as a separate course, where critical thinking skills and abilities are emphasized outside the context of specific subject matter. Some content is involved to contextualize examples and tasks (Ennis, as cited in (Lai, 2011). Strands of simplified literature were combined with real life stories and situations for which the participants were asked 
to think about, analyze and make decisions based on their own judgments. Their decisions were then analyzed through debates and discussions and conclusions were drawn in class. It was intended to create a clear concept of critical thinking in the minds of the participants and the exercises and examples given were designed to trigger critical thinking in students when making decisions or analyzing situations through debates and group/pair discussions.

\section{Procedure}

The study involved taking two groups of female Iranian adult intermediate learners, with one group attending 20 sessions of general English training as the control group, and the experimental group receiving additional training in critical thinking during sixteen of the general English sessions. The students' level of speaking proficiency was assessed before and after the training sessions to determine any changes made as a result of the treatment that they received. In order to avoid any threats to the reliability of the scores, the pretest and posttests were scored by the researcher and a second scorer. The mean of the two scorers' scores for each participant was calculated and reported as the participant's test score.

After the posttest results were collected, in-depth interviews were conducted with the participants for their opinion on the sessions in critical thinking, their on-going thoughts and how, they believe, thinking critically affected their speaking outcome in the posttest. The interview questions are listed in appendix A. The interviews were recorded on tape and were later reviewed to produce field notes in conjunction with observations, and casual encounters with subjects. It is expected that other data will be obtained throughout the study, such as comments from the subjects, papers or other materials they care to give in, and ongoing literature review.

A mixed-methods design was employed in this study. Greene, Caracelli and Graham (1989) defined mixed methods research designs as those that include at least one quantitative method (designed to collect numbers) and one qualitative method (designed to collect words). This study includes a qualitative and a qualitative approach. In the quantitative approach of this study a quasi-experimental design was utilized; and for the qualitative approach, in-depth interviews were conducted and studied.

\section{RESULTS AND DisCUSSIONS}

\section{A. Quantitative Analysis}

In the quantitative approach of this study, the answer to the following question was pursued: Does teaching critical thinking explicitly have an impact on the speaking proficiency of female Iranian adult intermediate EFL learners?

The data was collected through a quasi-experimental design and were analyzed using a quantitative approach. The SPSS (Statistical Package for the Social Sciences) software was employed to analyze the data collected from the control group and the experimental group.

Forty-eight intermediate students took the PET test, the scores varied from 21 to 98 out of 100. All those who scored between one standard deviation above and below the mean were selected and randomly assigned to two groups.

TABLE 1:

DESCRIPTIVE STATISTICS; PET

\begin{tabular}{llllll}
\hline & $\mathrm{N}$ & Minimum & Maximum & Mean & Std. Deviation \\
\hline PET & 48 & 21 & 98 & 67.74 & 14.151 \\
\hline
\end{tabular}

A speaking test was given to the participants before the experiment was carried out. The same test was repeated after the twenty class sessions were over. The total number of scores was increased to 30 for each group by bootstrapping the scores of the control group and the experimental group. An independent t-test was run to compare the experimental and control groups' mean scores on the gained score of the speaking test. As displayed in Table 1 the mean scores for experimental and control groups on gained score of speaking are 3.53 and 1.87 respectively.

TABLE 2:

\begin{tabular}{|c|c|c|c|c|}
\hline gender & $\mathrm{N}$ & Mean & Std. Deviation & Std. Error Mean \\
\hline Experimental & 30 & 3.53 & 3.421 & .625 \\
\hline Control & 30 & 1.87 & 2.209 & .403 \\
\hline
\end{tabular}

The results of the independent $\mathrm{t}$-test $(\mathrm{t}(58)=2.27, \mathrm{P}=.029<.05, \mathrm{r}=.28)$, with an almost moderate effect size, indicated that there is a significant difference between experimental and control groups' means on the gained score of speaking. Thus, the first null-hypothesis as the experimental group does not make a significantly better progress in their ability to speak English than the control group is rejected. As displayed in Table 1 the experimental group shows a higher gained score on the speaking test. 
TABLE 3:

INDEPENDENT T-TEST GAINED SCORES OF SPEAKING BY GROUPS

\begin{tabular}{|c|c|c|c|c|c|c|c|c|c|}
\hline & \multicolumn{2}{|c|}{\begin{tabular}{|l|} 
Levene's Test for \\
Equality of Variances
\end{tabular}} & \multicolumn{7}{|c|}{ t-test for Equality of Means } \\
\hline & \multirow[t]{2}{*}{$\mathrm{F}$} & \multirow[t]{2}{*}{ Sig. } & \multirow[t]{2}{*}{$T$} & \multirow[t]{2}{*}{$\mathrm{Df}$} & \multirow[t]{2}{*}{$\begin{array}{l}\text { Sig. (2- } \\
\text { tailed) }\end{array}$} & \multirow[t]{2}{*}{ Mean Difference } & \multirow[t]{2}{*}{$\begin{array}{l}\text { Std. Error } \\
\text { Difference }\end{array}$} & \multicolumn{2}{|c|}{$\begin{array}{l}95 \% \text { Confidence Interval } \\
\text { of the Difference }\end{array}$} \\
\hline & & & & & & & & Lower & Upper \\
\hline \begin{tabular}{|l|} 
Equal variances \\
assumed
\end{tabular} & 3.153 & .081 & 2.242 & 58 & .029 & 1.667 & .744 & .178 & 3.155 \\
\hline $\begin{array}{l}\text { Equal variances } \\
\text { not assumed }\end{array}$ & & & 2.242 & 49.594 & .029 & 1.667 & .744 & .173 & 3.160 \\
\hline
\end{tabular}

It should be noted that the assumption of homogeneity of variances is met (Levene's $\mathrm{F}=3.15, \mathrm{P}=.081>.05$ ). That is why the first row of Table 2, i.e. "Equal variances assumed" is reported.

\section{B. Qualitative Analysis}

The qualitative approach in this study was meant to answer the following questions:

1- How is the impact made on the speaking proficiency of the participants by raising critical thinking awareness explained?

2- What are the different attitudes that learners have towards critical thinking training and effectiveness of the training sessions?

In-depth interviews were conducted in pursue of answers to the above questions. The interviews were then transcribed and thoroughly studied. The results are revealed in the following.

Participants A, C, D, E, F, G, I, L, M and N claimed that they had previously not heard the term critical thinking (either in English or Persian), nor the concept of critical thinking or any of the principles. Participants B, H, and K claimed that they had not heard of the term "critical thinking" prior to the training sessions, but were slightly familiarized with some of the concepts through experience. Only participant J stated that she had been familiar with all the underlying principles of critical thinking previously through research, but stated that she was not aware that they were labeled as critical thinking.

All the participants found the training sessions in critical thinking extremely fruitful, except for participant $\mathbf{J}$ who claimed that they had slightly influenced her and revised what she had already known. All the other participants believed that the training they received in critical thinking had somehow influence their thinking or their mind and found the training very useful. Participants F, M and N described the experience as life-changing and explained that it had had a huge impact on their lives and the decisions they made.

Participants A, B, D, E, F, I, L, M and N thought that the new vocabulary which they had to use to express their ideas in the discussions and analyses were greatly internalized, helping the improvement made in their speaking proficiency. They claimed that the vocabulary learnt in these sessions will not be forgotten. Participants A, B, C, F, G, H, K and M also pointed out to the importance of the discussions carried out during the training sessions and mentioned that they practiced speaking in a very fruitful way and that is how the improvement in their speaking ability was made. Participant E believed that the English material used to teach critical thinking help her speaking ability most. Participant L claimed that listening to the teacher speak had had the most influence on her speaking ability (as the teacher spoke native-like English) and Participant $\mathbf{J}$ believed that the course as a whole was beneficial to her English speaking proficiency and that the critical training sessions, in particular, did not have a significant impact.

Participants E, G and I felt that the critical thinking material could not be self-studied and that the help of a teacher was essential. Participants A, B, C, D, I, J, K, L and M believed that the discussions and analyses of the subjects in class were more fruitful and informative than the reading the literature. However, participants E, F, G, H, K and N stated that the literature and the discussions and examples given were intertwined and one would not be as efficient without the other.

Participants A, B, C, E and N stated that critical thinking must be taught in classes for all people in society and participant $\mathrm{E}$ insisted that the classes be compulsory for all. Participants D, F, G, I, J, H, M and N believed that critical thinking must be taught explicitly at universities in Iran in exclusive courses. Participants D, F, I, J, L and N thought that critical thinking training must start at schools to give students an earlier insight into the issue. Participants D, F and $\mathrm{G}$ believed that explicit critical thinking training must take place at English language institutes. Participant M believed that critical thinking had better be taught in English as the resources are mostly in English.

\section{CONCLUSIONS AND IMPLICATIONS}

The first finding of this study revealed that raising critical thinking awareness explicitly has a significantly positive impact on the speaking proficiency of female Iranian adult intermediate EFL learners. This aligns with the findings of a similar study conducted by Malmir and Shoorcheh (2012) in which they concluded that a critical thinker is a better language learner. The findings are also in agreement with the results of the study carried out by Cosgrove (2011) in Oxford University who concluded that there was a need for an explicit and systematic approach to teaching critical 
thinking as the students internalized the explicit and required aspects of critical thinking and largely missed those that were implicit. Drawing from the literature on expertise, Van Gelder (2005) argued that students need "deliberate practice" in exercising critical thinking skills and abilities. This type of practice can only occur when critical thinking is taught as a separate and explicit part of the curriculum. Similarly, Halpern (as cited in Lai, 2011) argued that instruction in general thinking skills taught as a "broad-based, cross-disciplinary" course, as done in the treatment in this study, is the most effective way of teaching critical thinking. However, the findings disagree with Pithers and Soden (2000) who rejected the view that critical thinking could be taught as a separate subject and believe that critical thinking should be viewed as a way of teaching and learning in any domain.

Based on the finding of this study, it is concluded that critical thinking must explicitly be taught at schools or universities in Iran. Lai (2011) went beyond this and included that explicit instruction dedicated to critical thinking skills, abilities, and dispositions should be built into all levels of the K-12 (kindergarten to the twelfth grade) curriculum, rather than being limited to junior high or high school students.

In this study deeper learning of the new vocabulary was observed in the course of critical thinking training. Fahim and Komijani (2010) also found a positive correlation between L2 vocabulary knowledge and critical thinking ability. In addition, they declared that the participants' critical thinking ability also correlated positively with their self-assessed degree of determination, memorization, cognitive, and meta-cognitive strategies of L2 vocabulary learning. Accordingly, Malmir and Shoorcheh (2012) revealed that enhancing critical thinking strategies can directly lead to learning a language better. They concluded that language teachers should try to include the explicit instruction of critical thinking strategies in the classrooms. Paul and Elder (2005) approve these results and declare that the utilization of critical thinking skills would help EFL students learn L2 vocabulary more effectively and profoundly."

In order to teach critical thinking skills, teachers need to possess these skills and be trained in critical thinking themselves (Lai, 2011). Therefore, to establish courses for explicit critical thinking training, it is necessary that teachers at English Language institutes attend sessions on explicit critical thinking instruction as a part of their teacher training course or their in-service training.

Several pedagogical implications emerged from the results of the present study. To start with, critical thinking can be explicitly taught in the English class, as an accelerator of the thinking ability as well as the speaking ability of the learners. This explicit instruction of critical thinking in the English class, according to the findings of the present study, can not only improve the quality of life of the students, but can also integrate higher order thinking into the process of language learning, and English speaking in particular, which can make a deeper impression of the language taught and therefore, benefit the students in various ways.

Critical thinking can be explicitly taught in Teacher Training Courses as a part of their pre-service or in-service training. Teachers can benefit from the positive effects of explicit critical thinking instruction and convey this to their students when they teach English language skills.

Critical thinking can be explicitly taught at universities in Iran as an individual, exclusive course. According to the participants in this study, it is expected that universities attempt to equip their students with critical thinking skills, and this can be more effective if the instruction takes place in exclusive courses for explicit critical thinking instruction,

Dual courses of critical thinking and English speaking, or critical thinking and English vocabulary could be held in English language institutes or at universities in order to equally improve critical thinking abilities and the speaking proficiency or knowledge of vocabulary of the learners as they are interchangeably effective in learning one another. The integration of explicit critical thinking instruction and English language skills, particularly speaking, not only creates a more profound impact on the students in learning English more effectively, but can be more intriguing and motivating for the students as they may find the instruction and the material more attractive, and they may find the classes more useful as more than one subject is being taught.

A shift can be made from the banking system of education in Iran to a more modern, problem-posing system of education, in which more thought is triggered by the educators into the learners. Although it sounds like a huge leap, establishing exclusive critical thinking courses to the curricula can accelerate the shift to a more modern, critical system of education in the country. As some of the participants of this study also noted, explicit instruction in critical thinking at an earlier age can be better internalized and can affect the society and communication among its members positively.

English language teaching supervisors should facilitate the process of explicitly teaching critical thinking skills in the classroom. This can make the English language classroom more effective, accelerate language learning, and motivate students to stay with the English language program for a longer period and prevent them from losing interest.

In order to complement the findings of the present study, some further research can be suggested:

1- The same kind of research should be done on a larger scale to support generalizations.

2- The same kind of research should be done on male Iranian EFL learners.

3- Further qualitative research should be done on how explicit training in critical thinking improves the speaking proficiency of learners.

4- Further qualitative research should be done on how explicit training in critical thinking improves the knowledge of vocabulary of learners. 
5- Research studies should be done on the problems of teaching critical thinking skills, both implicitly and explicitly, in the system of education in Iran in in order to better understand why critical thinking is not currently taught in the system of education in Iran.

6- Research studies should be done on the problems of teaching critical thinking skills, both implicitly and explicitly, in EFL classes in Iran.

7- Studies should be done on the attitudes of EFL teachers of employing critical thinking techniques in the EFL class.

8- A correlational study can be conducted to compare the level of critical thinking in Iranian students who have studied ELT books which employ critical thinking strategies and those who have never studied English outside school.

\section{APPENDIX A}

Qualitative Interview Questions

Personal Background

1- How old are you?

2- Are you married?

3- What is your job?

4- What is your highest qualification and in what field?

Critical thinking

5- What do you think about critical thinking?

6- Had you heard of critical thinking or its concept before?

7- What do you think about the session we spent studying critical thinking? Did you find them useful? In what way?

8- Did you find the critical thinking sessions influential on your English speaking ability? If so, how?

9- Which part of the training did you find more useful? The literature or the discussions and examples?

10- Do you think critical thinking should be taught at schools or universities or English institutes?

\section{REFERENCES}

[1] Alagozlu, N. (2007). Creitical thinking and voice in EFL writing. Asian EFL Journal, 9(3), 118-136.

[2] Arum, R., \& Roksa, J. (2009). Academically adrift: Limited learning on college campuses. Chicago: University of Chicago Press.

[3] Bailin, S. (2002). Critical thinking and science education. Science and Education, 11(4), 361-375.

[4] Bailin, S., Case, R., Coombs, J. R., \& Daniels, L. B. (1999). Conceptualizing critical thinking. Journal of Curriculum Studies, 31(3), 285-302.

[5] Bloom, B. S. (1956). Taxonomy of educational objectives, handbook I: The cognitive domain. New York: David McKay Co Inc.

[6] Brown, H. D. (2004). Some practical thoughts about students- sensitive critical pedagogy. The Language Teacher, 6(23), 23-27.

[7] Bruning, R. H., Schraw, G. J., Norby, M. M., \& Ronning, R. R. (2004). Cognitive Psychology and Instruction. Upper Saddle River, NJ: Meril Prentice Hall.

[8] Bygate, M. (1987). Speaking. Oxford: Oxford University Press.

[9] Case, R. (2005). Moving critical thinking to the main stage. Education Canada, 45(2), 45-49.

[10] Cosgrove, R. (2011). Critical thinking in the Oxford tutorial: A call for an explicit systematic approach. Higher education research and development, 30(3), 343-356.

[11] Damirchi, Q. V., Seyyedi, M. H., \& Rahimi, G. (2012). Evaluation of knowledge and critical thinking at Azad Islamic University. Interdisciplinary Journal of Contemporary Research in Business, 3(9), 213-221.

[12] Devine, T. G. (1962). Critical thinking in the English class. Peabody journal of education, 39(6), 359-365.

[13] Ennis, R. H. (1989). Critical thinking and subject specificity: Clarification and needed research. Educational Researcher, 18(3), 4-10.

[14] Facione, P. A. (1990). Critical thinking: A statement of expert concensus for purposes of educational assessment and instruction. C.A.: The California Academic Press.

[15] Fahim, M., \& Komijani, A. (2010). Critical thinking ability, L2 vocabulary knowledge and L2 vocabulary learning strategies. Journal of English studies, 1(1), 23-38.

[16] Fahim, M., \& Shakouri, N. (2012). Critical thinking in higher education: A pedigogical look. Theory and practice in language studies, 2(7), 1370-1375.

[17] Fisher, A. (2003). An introduction to critical thinking. Mahwan, NJ: Lawrence Erlbaum.

[18] Florez, M. C. (1999). Improving Adult English Language Learners' Speaking Skills. Washington: Center for Applied Linguistics.

[19] Folse, K. (2006). The art of teaching speaking. Michigan: Michigan University Press.

[20] Freire, P. (1970). Pedagogy of the oppressed. New York: Seabury Press.

[21] Fulcher, G. (2003). Testing second language speaking. New York: Pearson Longman.

[22] Greene, J. C., Graham, W. F., \& caracelli, V. J. (1989). Toward a conceptual framework for mixed mtehod evaluation designs. Educational evaluation and policy analysis, 11(3), 255-274.

[23] Halpern, D. F. (2001). Assessing the effectiveness of critical thinking instruction. The Journal of General Education, 50(4), 270-286.

[24] Halpern, D. F. (2003). Thought and Knowledge: An introduction to critical thinking (4th ed.). Mahwah, NJ: Lawrence Erlbaum Associates. 
[25] Hughes, W., \& Lavery, J. (2004). Critical thinking: An introduction to the basic skills (4th ed.). CA: Broadview Press.

[26] Kennedy, M., Fisher, M. B., \& Ennis, R. H. (1991). Critical thinking: Literature review and needed research. In L. Idol, \& B. F. Jones (Eds.), Educational values and cognitive instruction: Implications for reform (pp. 11-40). New Jersey: Lawrence Erlbaum \& Associates.

[27] Ketabi, S., Zabihi, R., \& Ghadiri, M. (2012). Critical thinking across the ELT curriculum: A mixed mtehods approach to analyzing L2 teachers' attitudes towards critical thinking instruction. International journal of research studies in education, 2(3), 1-10.

[28] Lai, E. R. (2011). Critical thinking: A literature review. Pearson's publications.

[29] Lewis, A., \& Smith, D. (1993). Defining higher order thinking. Theory into Practice, 32(3), 131-137.

[30] Lipman, M. (1988). Critical thinking - What can it be? Educational Leadership, 46(1), 38-43.

[31] Lipman, M. (2003). Thinking in Education. West Nyack, New York: Cambridge University Press.

[32] Long, C. (2003). Critical Thinking and English Education. Pan-Pacific Association of Applied Linguistics, 215-224.

[33] Malmir, A., \& Shoorcheh, S. (2012). An investigation of the impact of teaching critical thinking on the Iranian EFL learners' speaking skill. Journal of Language Teaching and Research, 3(4), 608-617.

[34] Marin, L. M., \& Halpern, D. F. (2010). Pedagogy for developing critical thinking in adolescents: Explicit instruction produces greatest gains. Thinking Skills and Creativity, 6(2011), 1-13.

[35] Mayfield, M. (2001). Thinking for Yourself: Developing Critical Thinking Skills through Reading and Writing. United States: Thomas Learning.

[36] McLoughlin, C., \& Luca, J. (2000). Cognitive engagement and higher order thinking through computer conferencing: We know why but do we know how? In A. Herrmann, \& M. M. Kulski (Ed.), 9th Annual Teaching Learning Forum (pp. 4-15). Perth: Curtin University of Techonlogy. Retrieved 8 22, 2013, from http://cleo.murdoch.edu.au/confs/tlf/tlf2000/mcloughlin.html.

[37] Moon, J. (2008). Critical thinking: An exploration of theory and practice. London: Routledge.

[38] Nikoopour, J., Amini Farsani, M., \& Nasiri, M. (2011). On the relationship between critical thinking and language learning strategies amon Iranian EFL learners. Journal of Technology and Education, 5(3), 195-200.

[39] Nunan, D. (2003). Practical English language teaching. Boston: McGraw-Hill.

[40] Orlich, D. C., Harder, R. J., Callahan, R. C., Trevisan, M. S., \& Brown, A. H. (2004). Teaching strategies: A guide to effective instruction. Belmont, CA: Wadsworth Cengage Learning.

[41] Paul, R. (1992). Critical thinking: What, why, and how? New Directions for Community Coleges, 1992(77), 3-24.

[42] Paul, R. (2004). The state of critical thinking today: The need for a substantive concept of critical thinking. Retrieved 6 17, 2013, from critical thinking: www.criticalthinking.org.

[43] Paul, R., \& Elder, L. (2005). The Miniature Guide to Critical Thinking: Concepts. Retrieved from The Foundation for Critical Thinking: www.criticalthinking.org.

[44] Paul, R., \& Elder, L. (2008). The miniature guide to critical thinking concepts and tools. Foundation for critical thinking press.

[45] Pithers, R. T., \& Soden, R. (2000). Critical thinking in education: A review. Educational Research, 236-249.

[46] Rosyati, A. R., \& Rosna, A. H. (2008). The relationship between critical thinking and language proficiency of Malaysian undergraduates. Proceedings of the EDU-COM 2008 International Conference. Sustainability in Higher Education: Directions for Change (pp. 373-384). Perth, Western Ausralia: Edith Cowan University. Retrieved from http://ro.ecu.edu.au/ceducom/36.

[47] Shangarffam, N., \& Mamipour, M. (2011). The impact of teaching critical thinking on Intermediate EFL learners' writing skill. American Journal of Scientific Research, 40, 119-125.

[48] Silva, E. (2008). Measuring Skills for the 21st Century. Washington DC: Education Sector. Retrieved from http://www.educationsector.org/usr_doc/MeasuringSkills.pdf.

[49] Soanes, C., \& Hawker, S. (2009). The Oxford dictionary of current English. Oxford: Oxford University Press.

[50] Sternberg, R. J. (1986). Critical thinking: Its nature, measurement, and improvement. Retrieved May 17, 2013, from National Institute of Education: http://eric.ed.gov/PDFS/ED272882.pdf.

[51] Van Gelder, T. J. (2005). Teaching critical thinking: Some lessons from cognitive science. College Teaching, 53(1), 41-46.

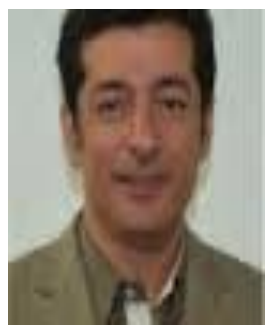

Reza Vahdani Sanavi is currently teaching English as a Foreign Language faculty member at IAU-Roudehen Branch. He has been in this field since the age of 19 at different English language institutes. He has also been teaching students different courses ranging from elementary courses to advanced levels, including FCE, CAE, CPE, IELTS and TOEFL. Dr Vahdani has published three books and some articles.

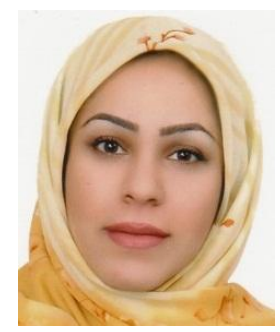

Samaneh Tarighat is an MA graduate of the Roodehen Islamic Azad University. She studied in the field of TESOL and has also worked in the field for the past twelve years in different ELT institutes. She is currently teaching at Kish institute located in Tehran. Ms Tarighat is the English editor of the quarterly of Professional Social Workers, published by Allameh Tabatabai University and has contributed to the translation of an encyclopedia. 